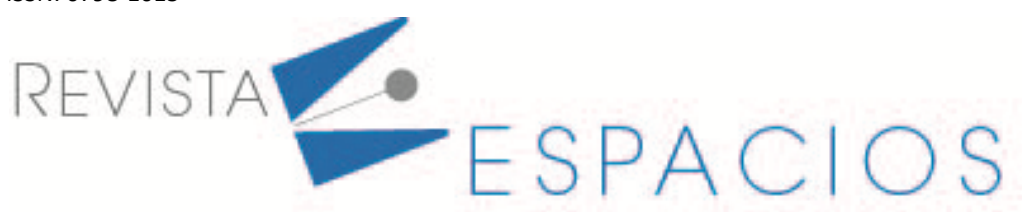

\title{
Comparative analysis of tourism observatories for their implementation in the City of Portoviejo-Manabí- Ecuador
}

\author{
Análisis comparativo de observatorios turísticos para su implementación en el cantón \\ Portoviejo-Manabí-Ecuador \\ CAICEDO CUESTA, Diana C. ${ }^{1}$ \\ ESCOBAR GARCÍA, Martha $C^{2}{ }^{2}$ \\ URETA ZAMBRANO, Maritza I. ${ }^{3}$
}

\begin{abstract}
The research carried out a comparative analysis of 15 national and international tourism observatories. For the design of the observatory, historical information, market studies, geographic location, information and communication technologies, collaboration and inter-institutional relations, expert opinions, among others, were considered. It has been concluded that the creation of an observatory favors the decision-making process of government actors and that they are relevant to the tourism sector, sustainability, and local socio-economical development.

key words: tourism observatory, local development, tourist models, tourist activity

Resumen

La investigación realizó un análisis comparativo de 15 observatorios turísticos nacionales e internacionales. Para el diseño del observatorio se debe considerar información histórica, estudios de mercado, localización geográfica, tecnologías de información y comunicación, colaboración y relaciones interinstitucionales, opiniones de expertos, entre otros. Se concluye que la creación de un observatorio favorece al proceso de toma de decisiones de los actores gubernamentales y que estén asociadas al sector turístico y a la sostenibilidad y desarrollo social y económico local.

Palabras clave: observatorio de turismo, desarrollo local, modelos turísticos, actividad turística
\end{abstract}

\section{Introduction}

Tourism has existed since ancient times. In fact, it is a phenomenon linked to the advances and evolution from nomadism to sedentary lifestyle, which corresponds to the first attempts of what is now known as tourism. However, it is worth noting that the term has been changing and adapting to the specifications and needs of different cultures, generating a worldwide potential increase from multilateral approaches.

In Ecuador, tourism has been strengthened since the insertion of the railway under the governments of García Moreno and Eloy Alfaro. Later, in 1930 Isidro Ayora facilitated the entry of travelers from other parts of the

\footnotetext{
${ }^{1}$ Estudiante de la Maestría en Desarrollo Local. Instituto de Posgrado. Universidad Técnica de Manabí, Ecuador. Ingeniera Comercial. Email: dcuesta82@hotmail.com

${ }^{2}$ Doctor en Ciencias Pedagógicas. Profesora de la Facultad Ciencias Administrativas y Económicas. Universidad Técnica de Manabí. Email: marthitae65@gmail.com

${ }^{3}$ Magister en Docencia e Investigación Educativa. Profesora de la Facultad Ciencias Administrativas y Económicas. Universidad Técnica de Manabí. Email: ec.irinuska_uz@hotmail.com
} 
world, and also advertised the natural resources that the country has. Since 1934, the Galapagos Islands have been seen as a natural reserve thanks to the diversity of endemic flora and fauna; but it was during the government of Enrique Gallo when a tourism law was created that provided an identification to travelers as a certificate of their prevalence in the country (GoRaymi, 2018).

In the country, there are considerable variations in regards to tourism, for the conservation of natural, cultural and historical species as part of social responsibility towards the environment, which has an impact on the improvement of the economy focused on trade and industry activities; therefore, diversification of tourism is key to take full advantage of tourist attractions.

According to the report of the Ministry of Tourism (2020) corresponding to the period 2016-2020, the international arrival per year are as follows (Figure 1):

Figure 1

Annual international arrivals in Ecuador

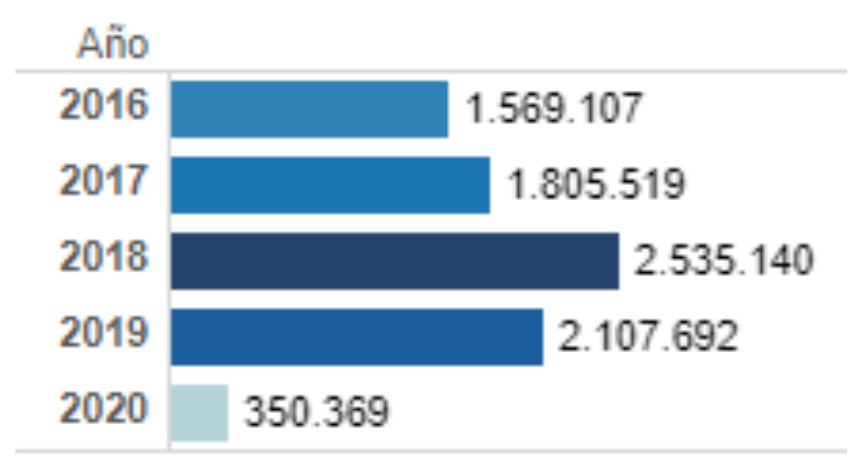

Source: Ministry of Tourism (2020)

Tourism fosters economical, environmental and social progress of a nation. The use of statistical data provided by regulatory entities reflect the weaknesses and strengths for efficient and effective decision-making that contribute to sustainable development (Godínez, 2014). Tourism made up 2.2\% of Ecuador's GDP in 2019; the estimated foreign exchange income from inbound tourism in 2019 was 2,287.50 (USD million). There are 477,382 employees in accommodation and food services and 24,257 tourist establishments registered according to the National Cadastre 2019 (Ministry of Tourism, 2020).

Tourism is considered the basis of economic development in the population, due to the considerable boost it generates as an agent of multilateral growth, although there is also the argument for measuring the growth and progress of the sector. That is the cornerstone that shows if the activities carried out so far are adequate to meet the needs of the population without harming the most vulnerable (Burgos, 2016).

The creation of establishments, ministries or organizations that are in charge of regulating the entry and exit of travelers is essential, for this allows greater control. The need to build an observatory is evident, which according to the Faculty of Hospitality and Tourism, ULEAM (2017) is an organization focused on providing reliable, systematic and transparent information, capable of documenting the evolution of tourist phenomena to evaluate, analyze and synthesize the knowledge acquired and that will favor future decisions.

Sarmiento, Delgado and Infante (2019) argue that an observatory aims to detail the evolution of the phenomena that are studied or observed, analyzing it from a social or economic perspective. It is a space where it is possible to identify, collect, process and manage the information that is obtained periodically and accurately using techniques and methodologies. An observatory collects relevant data for studies, contributing to decisionmaking as a boost to progress. 
Consequently, Gallardo, Santa Cruz, Cazorla and Mesa (2016), define tourist observatories as establishments that provide timely, clear and quality information for management decision-making, collectively and individually, that observes tourism activity, to increase the competitiveness of this sector continuously. On the other hand, Blasco \& Cuevas (2013) point out that tourism observatories are intelligence instruments, at the service of tourist destinations, designed to provide strategic information on tourist activity, which helps the sustainable development of destinations.

Likewise, Mendoza, Yumisaca, Freire, and Ullari (2016) propose that the base of tourist observatories is to turn them into a chain of systems that is capable of evaluating, organizing, capturing and processing information, in order to follow up on sustainable tourism in the sectors where said institutions are established; In addition, they serve as support in decision-making, to make projections of possible scenarios and characterize the situation of the locality.

The city of Portoviejo, regarding tourism, has noted shortcomings in obtaining statistical data for the entry of travelers, arguing that, following the $16 \mathrm{~A}$ earthquake, various strategies have been implemented to promote tourism: solidarity tour, gastronomic festivals, cultural and sports events and social media campaigns (Félix, Campos, Martí, \& Mejía, 2017). It is also emphasized that tourism is part of the sustainable development of towns, so it is essential that the strategic planning that allows and facilitates the obtaining of pertinent documentation is managed and properly executed, as a basis for tourism regulation in Portoviejo.

One of the main advantages of the city is its geostrategic location, seen as an opportunity to encourage "commercial tourism, artistic shows, adventure tourism and ethnotourism linked to the presence of nationalities" (National Secretary for Planning and Development, 2019, pg. . fifteen). With this, it is more evident that the city seeks to improve strategies at the tourist level, because it is where the main economic income is concentrated, which allows growth and sustainable development.

It is also exposed that the need for information in tourism management requires alternatives that contribute to the satisfaction of visitors, tourists and the local development of Portoviejo. In this sense, Universities play an important role, because they have intellectual capital and the possibility of establishing strategic alliances with public and private entities in the tourism sector.

Therefore, the creation of a tourism observatory in Portoviejo should be discussed, taking into consideration the different approaches and structures that contribute to the economy and benefit tourism companies, visitors and the community in general; Portoviejo has a great diversity of historical, cultural and natural heritage that constitutes an attraction for national and international tourists.

\section{Methodology}

\subsection{Type of study}

This investigation was carried out through documentary analysis, which implies the "analysis and synthesis of the similarities, differences and patterns of two or more cases that share a common approach or goal [...] usually incorporating both qualitative and quantitative data for the understanding the cases and their context" (Goodrick, 2014, p. 1).

\subsection{Analysis technique}

For the documentary analysis, data was obtained from secondary sources on the websites of government and municipal institutions, as well as websites of observatories and universities; Bibliographic records were constructed. In order to build the tourism observatory of Portoviejo, oriented to the specific needs of the sector, 15 models of national and international tourism observatories were analyzed, in different tourist lines

\subsection{Criteria for document selection}


The selection began with the search for national and international observatorie in operation, which would show information about the form of operation, functions, products and services, indicators. Table 1, details the observatories that are part of the study. The comparative analysis of the 15 observatories, taking into consideration the functions they perform (Table 2), the goods and services they offer (Table 3), their way of presenting information (Table 4) and the forms of operation (Table 5).

Table 1

Sample Observatories

\begin{tabular}{|c|c|c|c|c|c|}
\hline Code & Observatory & Institution in charge & Country & Year & Status \\
\hline 1-OTG & $\begin{array}{l}\text { Observatorio Turístico } \\
\text { Científico de la ciudad de } \\
\text { Guayaquil }\end{array}$ & $\begin{array}{l}\text { Municipalidad de Guayaquil. } \\
\text { Universidad Espíritu Santo }\end{array}$ & Ecuador & 2015 & In operation \\
\hline 2-OTRS & $\begin{array}{l}\text { Observatorio Turístico } \\
\text { Región Sur del Ecuador }\end{array}$ & $\begin{array}{l}\text { Universidad Técnica } \\
\text { Particular de Loja }\end{array}$ & Ecuador & 2016 & In operation \\
\hline 3-OTS & $\begin{array}{l}\text { Observatorio Turístico } \\
\text { Sostenible }\end{array}$ & $\begin{array}{l}\text { Universidad Estatal Península } \\
\text { de Santa Elena }\end{array}$ & Ecuador & 2017 & In operation \\
\hline 4-OT & Observatorio Turístico & $\begin{array}{l}\text { Universidad Estatal } \\
\text { Amazónica }\end{array}$ & Ecuador & 2018 & In operation \\
\hline 5-OTG & $\begin{array}{l}\text { Observatorio Turístico } \\
\text { Galápagos }\end{array}$ & Ministerio de Turismo & Ecuador & 2011 & In operation \\
\hline 6-OTP & $\begin{array}{l}\text { Observatorio Turístico del } \\
\text { Perú }\end{array}$ & $\begin{array}{l}\text { Universidad de San Martín de } \\
\text { Porres }\end{array}$ & Perú & 2011 & In operation \\
\hline 7-OTG & $\begin{array}{l}\text { Observatorio Turístico } \\
\text { Guía }\end{array}$ & $\begin{array}{l}\text { Universidad Pedagógica y } \\
\text { Tecnológica de Colombia }\end{array}$ & Colombia & 2014 & In operation \\
\hline 8-OTSC & $\begin{array}{l}\text { Observatorio de Turismo } \\
\text { Sostenible del Caribe }\end{array}$ & Universidad de Costa Rica & Costa Rica & 2004 & In operation \\
\hline 9-OTSD & $\begin{array}{l}\text { Observatorio Turístico de } \\
\text { Santo Domingo }\end{array}$ & $\begin{array}{l}\text { Ministerio de Turismo. Banco } \\
\text { Iberoamericano de Desarrollo }\end{array}$ & $\begin{array}{l}\text { Dominican } \\
\text { Republic }\end{array}$ & 2015 & In operation \\
\hline $\begin{array}{l}10- \\
\text { OUTSCC }\end{array}$ & $\begin{array}{l}\text { Observatorio } \\
\text { Universitario de Turismo } \\
\text { Sostenible y Cambio } \\
\text { Climático }\end{array}$ & $\begin{array}{l}\text { Universidad Nacional } \\
\text { Autónoma de Honduras }\end{array}$ & Honduras & 2015 & In operation \\
\hline $\begin{array}{l}11- \\
\text { OTBA }\end{array}$ & $\begin{array}{l}\text { Observatorio Turístico de } \\
\text { Buenos Aires }\end{array}$ & $\begin{array}{l}\text { Gobierno de la Ciudad de } \\
\text { Buenos Aires }\end{array}$ & Argentina & 2009 & In operation \\
\hline 12-OT & Observatorio Turístico & $\begin{array}{l}\text { Ayuntamiento de Málaga } \\
\text { Universidad de Málaga }\end{array}$ & Spain & 2008 & In operation \\
\hline $\begin{array}{l}13- \\
\text { OTEG }\end{array}$ & $\begin{array}{l}\text { Observatorio Turístico del } \\
\text { Estado de Guanajuato }\end{array}$ & $\begin{array}{l}\text { Secretaría de Turismo del } \\
\text { Estado de Guanajuato }\end{array}$ & México & 2010 & In operation \\
\hline 14-OTG & $\begin{array}{l}\text { Observatorio Turístico de } \\
\text { Guadalajara }\end{array}$ & $\begin{array}{l}\text { Concejalía de Turismo del } \\
\text { Ayuntamiento de Guadalajara }\end{array}$ & México & 2009 & In operation \\
\hline 15-OTE & $\begin{array}{l}\text { Observatorio Turístico de } \\
\text { Euskadi }\end{array}$ & Gobierno Vasco & Spain & 2010 & In operation \\
\hline
\end{tabular}

Source: Authors

$47 \%$ of the observatories are managed by universities; $40 \%$ by government tourism agencies and $13 \%$ by universities and government agencies. The contribution of the observatories to the national planning, economy and academic sector is evident.

$66.67 \%$ of the sample corresponds to international observatories and $33.33 \%$ to national observatories. In this way, there is a point of view from other contexts about the organization, operation and elements that make up the observatories. 
$40 \%$ of the observatories have been active for $1-5$ years; $27 \%$ for $6-11$ years and $33 \%$ between $11-15$ years. It is evident that the countries are concerned with obtaining tourism data for internal and foreign visitors. $100 \%$ of the observatories under study are in operation.

\section{Results}

\subsection{Observatory functions}

The observatories were created in order to generate tourist data, analyze tourism developments, support decision-making, contribute to tourism planning and generate information to propose alternative solutions to enhance the tourism sector. They also generate knowledge through lines of research and projects. It can be perceived that tourism observatories serve as research centers, where development alternatives are obtained, analyzed and proposed.The information obtained in the observatories is up-to-date, making it an appropriate management tool for establish the link with the public, private, academic sector.

Table 2

Observatory functions

\begin{tabular}{|c|c|}
\hline Code & Function \\
\hline 1-OTG & Generate statistical data of national and international tourists demand \\
\hline 2-OTRS & Facilitate data to the economical agents of the tourism sector and assess the impact of public policies. \\
\hline 3-OTS & $\begin{array}{l}\text { Follow the pace of touristic evolution, behavior and trends; propose measures to improve the } \\
\text { competitiveness of products and destiantions of the province }\end{array}$ \\
\hline 4-OT & Generate statistical data of tourism activites of the Pastaza province and the Amazon region \\
\hline 5-OTG & $\begin{array}{l}\text { Generate dynamic data of the Islands' tourism activites, for decision-making focused on the ecotourism } \\
\text { model of the province }\end{array}$ \\
\hline 6-OTP & Assess work plans from investment and advertisementpolicies in the tourism sector \\
\hline 7-OTG & $\begin{array}{l}\text { Provide data to whoever interested in the tourism sector, as well as academics, entrepeneurs and } \\
\text { government agents. Produce knowledge for Science, Technology and Innovation }\end{array}$ \\
\hline 8-OTSC & $\begin{array}{l}\text { Observation, recopilation, generation and interdisciplinary technical analysis of data from various } \\
\text { organized sectors to overlook, verify and measure the tourism sector's evolution onthe caribbiean coast } \\
\text { of Costa Rica }\end{array}$ \\
\hline 9-OTSD & It is a research initiative and it will contribute to the tracing of the dynamics of the visitors to the city \\
\hline 10-OUTSCC & $\begin{array}{l}\text { Generate, systematize and spread information that is pertinent and relevant to contribute to } \\
\text { sustainable growth of the toursim sector. }\end{array}$ \\
\hline 11-OTBA & $\begin{array}{l}\text { Generate market data for decision making in the public sector, companies and professionals, increasing } \\
\text { the potential of tourism as a strategic activity for the socio-economical development of the city of } \\
\text { Buenos Aires }\end{array}$ \\
\hline 12-OT & $\begin{array}{l}\text { Have thorough knowledge of the rules and guidelines of the visit and profile from visitors, tourists, } \\
\text { excursionists as well as other characteristics. }\end{array}$ \\
\hline 13-OTEG & Overlook, measure and verify the assessment of the toruism sector in the State of Guanajuato. \\
\hline 14-OTG & $\begin{array}{l}\text { Know the characteristics, expectations and level of satisfaction of the visitors. Assure the accuracy of } \\
\text { decision, strategy and performance of the public and private sector }\end{array}$ \\
\hline 15-OTE & $\begin{array}{l}\text { Generate data about tourism GDP, its importance as a occupational activity, qualification and formation } \\
\text { of the tourism sector }\end{array}$ \\
\hline
\end{tabular}

Source: Authors

\subsection{Goods and services}

Observatories describe the goods and services they will cover. Most report on the information that the locality offers to its visitors. Many use analysis variables proposed by the UNWTO (World Tourism Organization), for 
example: accommodation, mobilization, restaurants, tourist places, among others; in addition, some show research indicators. The employment variable is analyzed only by a few observatories. The evaluation of quality of service, demand, tourist's time of stay in the destination, is obtained through surveys, which are done in various ways, such as in places of accommodation, airports, web pages, and others.

Table 3 summarizes the goods and services offered by the observatories in this study.

Table 3

Goods and services offered by the observatories

\begin{tabular}{|c|c|}
\hline Code & Goods and services \\
\hline 1-OTG & $\begin{array}{l}\text { Scientific, academic and social indicators of the current situation of tourist activity in the city. } \\
\text { Strategies for the development and sustainability of tourism. }\end{array}$ \\
\hline 2-OTRS & $\begin{array}{l}\text { Tourist profiles. } \\
\text { Supply and demand newsletters. } \\
\text { Others resulting from the crossing of data and variables of interest. }\end{array}$ \\
\hline 3-OTS & $\begin{array}{l}\text { Journals. Publications. } \\
\text { Market research. Statistical information. } \\
\text { Tourism Profiles }\end{array}$ \\
\hline 4-OT & Tourist barometer. Newsletters. Graphic Statistics. \\
\hline 5-OTG & Online viewers. \\
\hline 6-OTP & $\begin{array}{l}\text { Research aimed at periodically evaluating the Tourism Satellite Accounts. } \\
\text { Quality measurement of destinations and tourist offer. } \\
\text { Strategic alliance with tourism, state and private companies. }\end{array}$ \\
\hline 7-OTG & $\begin{array}{l}\text { Characterization of tourism service providers. } \\
\text { Market research. } \\
\text { Tourist product design. } \\
\text { Information management }\end{array}$ \\
\hline 8-OTSC & $\begin{array}{l}\text { Indicators and Statistics. Related projects. Scientific articles. } \\
\text { Information about the Caribbean. Research on the Caribbean. }\end{array}$ \\
\hline 9-OTSD & $\begin{array}{l}\text { Tourist barometer } \\
\text { Statistical data and indicators of the tourism situation in the areas of demand, supply, economy } \\
\text { and destination management. }\end{array}$ \\
\hline 10-OUTSCC & $\begin{array}{l}\text { Economic, environmental, short, medium and long-term indicators. } \\
\text { Lines of research }\end{array}$ \\
\hline 11-OTBA & $\begin{array}{l}\text { Tourist Intelligence System, a digital platform that will allow you to dynamically visualize the } \\
\text { main tourism data from multiple sources of information. }\end{array}$ \\
\hline 12-OT & $\begin{array}{l}\text { Systematized, ordered and updated data on tourist activity. } \\
\text { Promotion and marketing strategies of the Tourism Area and the destination. } \\
\text { Design of segmentation techniques for the universe of tourists. }\end{array}$ \\
\hline 13-OTEG & Tourism barometer \\
\hline 14-OTG & $\begin{array}{l}\text { Links of interest: Notice board. } \\
\text { Electronic headquarters. Full broadcast. FEDER funds }\end{array}$ \\
\hline 15-OTE & $\begin{array}{l}\text { Statistical area. } \\
\text { Tourism area. } \\
\text { Investigation area. } \\
\text { Broadcast área }\end{array}$ \\
\hline
\end{tabular}

Source: Authors

\subsection{Showcase of data}

Tourism observatories offer and present statistical, tourist, economic and scientific information through website, bulletins, monthly, quarterly, semi-annual or annual reports. They analyze indicators of sustainable 
development, climate, tourism activity, tourism markets, quantitative and qualitative data on the destination, among others. Table 4 describes the ways the information is presented:

Table 4

Ways of showcasing information

\begin{tabular}{ll}
\hline \multicolumn{1}{c}{ Code } & \multicolumn{1}{c}{ Ways of showcasing information } \\
\hline 1-OTG & Statistical reports prepared by the UEES. \\
\hline 2-OTRS & Reports with quantitative and qualitative information on the tourist movement in the area. \\
\hline 3-OTS & Reports on systems of indicators of sustainable development. \\
\hline 4-OT & R Statistical reports of the tourist activity of the province. \\
\hline 5-OTG & Updated online viewers. \\
\hline 6-OTP & BADATUR tourism data bank. \\
\hline 7-OTG & Annual Tourist Bulletin with the selected indicators. \\
\hline 9-OTSC & Information about the Caribbean. Touristic offer. History. Culture. Transport. \\
\hline 10-OUTSCC & Tourism Promotion Program. Tourist Barometer. Official Publications. \\
\hline 11-OTBA & Special bulletin \\
\hline Periodic reports with key projection indicators. \\
Big Data techniques to analyze information and better understand the environment. \\
Qualitative research on the behavior of tourist segments and markets. \\
\hline $\begin{array}{l}\text { Annual reports, structured in three different conceptual blocks: } \\
\text { The tourist offer in the city. }\end{array}$ \\
$\begin{array}{l}\text { Economic impact caused by travel in the city. } \\
\text { Characterization of visitors to the city of Malaga. }\end{array}$ \\
\hline 13-OTEG & Statistical reports of satisfaction index of national and international visitors, private investments \\
\hline 14-OTG & $\begin{array}{l}\text { Quantitative and qualitative data on the tourist situation: supply and demand in annual } \\
\text { newsletters }\end{array}$ \\
\hline 15-OTE & Synthetic and visual reports and through an intuitive and easy to use interface \\
\hline
\end{tabular}

Source: Authors

\subsection{Forms of operation of the observatories}

Most of the observatories are managed by public and private universities; some are managed by national government agencies in the tourism sector and local government such as municipalities and town halls. Likewise, they maintain international rapport with entities of tourism, development and research around the world. Collaborative work between the public, private and academic sectors for the generation of information is strengthened. Table 5 shows the forms of operation of the observatories.

Tabla 5

Forms of operation

\begin{tabular}{|c|c|}
\hline Code & Forms of operation \\
\hline 1-OTG & $\begin{array}{l}\text { Reollection of statistical information on the international tourist demand and the national tourists that } \\
\text { visit the city. } \\
\text { It generates quality information, updated and regularized by the research methodology of the World } \\
\text { Tourism Organization (UNWTO), ECLAC and with the guidelines of the Ministry of Tourism of Ecuador. }\end{array}$ \\
\hline 2-OTRS & $\begin{array}{l}\text { It works with information collected through an application and data generated by hotel establishments } \\
\text { through the Ministry of Tourism of Zone } 7 . \\
\text { Data gathering executed by teachers and students from the Hospitality and Tourism, Gastronomy, } \\
\text { Business Administration and Economics courses. }\end{array}$ \\
\hline 3-OTS & Diagnostic system based on tourism and sustainability indicators. \\
\hline 4-OT & $\begin{array}{l}\text { Reporting systems based on: News about numbers of residents. } \\
\text { Reports by geographic location of location anchored to the UEA GIS unit. Visit reports by topic. }\end{array}$ \\
\hline
\end{tabular}




\begin{tabular}{|c|c|}
\hline Code & Forms of operation \\
\hline 5-OTG & $\begin{array}{l}\text { It works within the framework of a technical group made up of various institutions that provide } \\
\text { information and make decisions based on the work of the observatory. } \\
\text { Collaborative work, comments and ideas from private sector actors, academia or public sector } \\
\text { institutions are considered. }\end{array}$ \\
\hline 6-OTP & $\begin{array}{l}\text { Planning entity that generates data through the quantitative and qualitative analysis of the fulfillment of } \\
\text { goals set by the competent authority. }\end{array}$ \\
\hline 7-OTG & $\begin{array}{l}\text { It provides top quality information to the tourism sector, academics, businessmen, government entities } \\
\text { and other interest groups. }\end{array}$ \\
\hline 8-OTSC & $\begin{array}{l}\text { It brings together various organized sectors (educational institutions, public institutions, the private } \\
\text { sector and non-governmental entities) to measure the evolution of tourism in the Caribbean and } \\
\text { contribute to the development of sustainable tourism. }\end{array}$ \\
\hline 9-OTSD & $\begin{array}{l}\text { It is fed by documents and information from national and international organizations, as well as its own } \\
\text { research, the results of which are analyzed and made available to professionals and specialists. Tourism } \\
\text { Promotion Council. Tourism Zones Infrastructure Executing Committee. Tourist Promotion, National and } \\
\text { International Offices. }\end{array}$ \\
\hline $\begin{array}{l}10- \\
\text { OUTSCC }\end{array}$ & $\begin{array}{l}\text { Measure indicators of sustainable tourism and climate change in a systematic way and with scientific } \\
\text { methodology, presenting information on the impacts that are generated in tourist destinations, at the } \\
\text { same time, it report the results of said measurement to establish sustainability in tourist destinations. }\end{array}$ \\
\hline 11-OTBA & $\begin{array}{l}\text { Relations with the public sector, companies and professionals, promoting tourism as a strategic activity } \\
\text { for the economic and social development of the City of Buenos Aires. }\end{array}$ \\
\hline $12-\mathrm{OT}$ & $\begin{array}{l}\text { Information on the tourist activity of the city is generated under the guidelines and supervision of the } \\
\text { Tourism Area of the Malaga City Council. }\end{array}$ \\
\hline 13-OTEG & $\begin{array}{l}\text { It works through a control panel, communicates the behavior of tourist indicators through a traffic light, } \\
\text { which are permanently monitored, showing the percentage of progress of the goals set in the Guanajuato } \\
\text { State Tourism Program. }\end{array}$ \\
\hline 14-OTG & $\begin{array}{l}\text { It processes information obtained through personal interviews in Spanish and English, made to visitors, at } \\
\text { different points of interest in the city such as the monuments of the Guadalajara Open program, the } \\
\text { Municipal Tourist Management Office. }\end{array}$ \\
\hline 15-OTE & $\begin{array}{l}\text { Search, unify and harmonize the information dispersed in different statistical sources, enriching and } \\
\text { facilitating its analysis. }\end{array}$ \\
\hline
\end{tabular}

Source:Authors

Thanks to the comparison that was done in the previous tables, it is evident that there are coinciding points, such as:

$\checkmark$ The creation of a tourism observatory influences economic, social and educational growth.

$\checkmark$ The observatory is a tool for generating tourist data, with analysis of indicators.

$\checkmark$ The observatory is a place for scientific, social, environmental and economic debate.

$\checkmark$ It is structured on the basis of supply, demand and tourist destination indicators.

$\checkmark \quad$ It allows to bring together natural benefits with economic resources.

$\checkmark$ It allows to control the statistics of national and foreign visitors.

$\checkmark$ The observatory shows the geographical location of tourist places and tourist services.

$\checkmark$ Information and communication technologies are used by all observatory models and serve to develop strategies and activities related to tourism.

$\checkmark$ There is collaboration between observatories, municipalities, the ministry of tourism and universities to interrelate the strengths of each link that is within the tourism offer.

$\checkmark$ International relations are maintained as a link to strengthen information regarding supply and demand.

Likewise, some existing differences in tourism observatories are identified:

$\checkmark$ The segment to which the tourist offer is destined, its particularities and potential.

$\checkmark$ Observatory type, in terms of organization and management.

$\checkmark$ Types of indicators, which are related to the mission and vision of each observatory. 
$\checkmark$ The observatories differ in that their indicators show the geographical, cultural, historical and environmental potential of each locality, which also implies that the needs and offers differ.

These contradictions serve as foundation to work out a proposal that armonizes the planned expectatives to create a tourism obervatory in the city of Portoviejo.

\subsection{Components}

The following are the items that correspond to the components that a tourism observatory must possess:

- Historical information: Corresponds to the historical background of the sector where the toruism observatory will be established.

- Market studies: Corresponds to a technique to measure whether the product or service to be implemented in the medium will be well-received or not.

- Geographical location: It includes the geographical location which, from a commercial approach, will be fundamental to improve the influx of customers.

- Information and communication technologies: They are the techniques and tools necessary to stay informed, in touch and up-to-date, according to the technological advances of the globalized world.

- Collaboration and inter-institutional relations: With this, strategies and processes between institutions can be managed and promoted, to finance them through agreements that are limiting in organizational development.

- Expert opinions on tourism: They can be entities or people with tourism as their field of action and knowledge, that contribute with relevant criteria for tourism development.

- Professionals in the field of tourism: Includes professionals in the field of tourism who are trained and contribute their knowledge, directly and indirectly in the theoretical construction of tourism and its development.

\subsection{Discussion}

The creation of a tourist observatory influences economic growth and job creation; In this sense, it coincides with the ideas presented by Soto (2017) in his work entitled "Theoretical and conceptual elements for the observation and monitoring of the tourist territory under sustainability criteria", where he states that tourism observatories are an initiative to control tourist activity in the environment in which they are working, hoping to obtain results that improve the market, the social and economic situation of the population.

The tourism observatory is an information-generating tool, therefore, the criteria of the Ministry of Tourism (2017) is shared in its publication on the institutional management of the Galapagos Tourism Observatory, where it states that the purpose of obtaining data from Tourist information facilitates users' access to platforms with updated information on tourism dynamics; This knowledge serves as the basis for decision-making by public and private entities and contributes to the development of tourism.

In addition, an observatory is the scene of social, environmental, scientific and economic debate, because establishment of these institutions has produced extensive development in various areas, such as gender violence, health, sustainability, globalization, social responsibility, technology, immigration, GDP increase, and other factors embedded in the aforementioned contexts (Instituto Nacional de Administración Pública AC, 2014).

An observatory is structured on the basis of indicators of supply, demand and tourist destinations. In relation to this, Báez (2017) mentions his work "Study of the historical evolution of tourist observatories worldwide" that The purpose of the tourism observatory is to analyse the tourism sector through the use indicators such as origin, means of transport, accommodation, travel, daily expenses and stay.

Likewise, considering the theoretical contributions presented in other documents, it is agreed that tourist observatories are a source of tourist information that serves as a reference for the development of business strategies that promote tourism. It should be noted that observatories of this type are based on bibliographic 
documentation, in relation to visitors and their drive in the growth or decrease in visits, accommodation, buyers and tourist activities, which are carried out in various tourist destinations.

\section{Conclusion}

A tourism observatory provides a boost to the economy, generates well-being in society and strengthens the internationalization of a locality. This is achieved through the visualization of historical, economic, environmental, social and cultural data, which motivate the choice of tourist destinations. Successful decisionmaking by various public and private actors is favored, as it contributes to the sustainability of the tourism sector and consequently to local development. Information and communication technologies are necessary in the implementation of a tourism observatory, for they allow us to offer updated, localized, dynamic and accessible information. However, it also becomes a barrier, due to the lack of economic and technological resources and lack of participation by the company. This type of observatory model may be applicable in the city of Portoviejo, since it has the required resources to generate benefits for the population, thanks to the diversity of its tourist attractions, which have not been potentiated. Therefore, it is the duty of institutions, especially of higher education, to consider the importance of creating a tourism observatory for the city.

\section{Bibliography}

Ayuntamiento de Guadalajara. (2016). Observatorio Turístico Guadalajara. Obtenido de guadalajara.es: https://www.guadalajara.es/es/turismo/area-profesional/observatorio-turistico/

Báez, S. (2017). Estudio de la Evolución Histórica de los Observatorios Turísticos a nivel mundial. (Tesis de Grado). Universidad Central del Ecuador. Obtenido de Universidad Central del Ecuador : http://www.dspace.uce.edu.ec/bitstream/25000/9667/1/T-UCE-0004-10.pdf

Blasco, D., \& Cuevas, T. (2013). Observatorio en turismo: organismo inteligente para la toma de decisiones en el destino. Revista Iberoamericana de Turismo, 3(2), 25 - 34. Obtenido de http://www.seer.ufal.br/index.php/ritur

Burgos, R. (2016). El turismo comunitario como iniciativa de desarrollo local. Caso localidades de Ciudad Bolívar y Usme zona rural de Bogotá. Hallazgos, 13(26), 193 - 214. Obtenido de http://www.scielo.org.co/pdf/hall/v13n26/v13n26a09.pdf

Facultad de Hotelería y Turismo, ULEAM. (2017). Observatorio Turístico de Manabí. (Proyecto Observatorio Turístico de Manabí). Obtenido de Universidad Laica Eloy Alfaro: http://carreras.uleam.edu.ec/hoteleriaturismo/wp-content/uploads/sites/35/2018/05/Proyecto-Observatorio-Tur\%C3\%ADstico-deManab\%C3\%AD.pdf

Félix, Á., Campos, S., Martí, J., \& Mejía, M. (2017). Recuperación de destinos turísticos posterremoto: revisión del caso Ecuador. Revista Venezolana de Gerencia, 22(8), 1 - 16. Obtenido de https://www.redalyc.org/jatsRepo/290/29055967006/html/index.html

Gallardo, G., Santa Cruz , R., Cazorla, M., \& Mesa, W. (2016). Observatorio turistíco para la sostenibilidad y competitividad turística de la ciudad de Guayaquil. ECOCIENCIA, 3(5), 1 - 25. Obtenido de http://ecociencia.ecotec.edu.ec/upload/php/files/octubre/04.pdf

Gobierno de Buenos Aires Argentina. (2018). Observatorio Turístico. Obtenido de turismo.buenosaires.gob.ar: https://turismo.buenosaires.gob.ar/es/observatorio

Godínez, R. (2014). Los Observatorios Turisticos como instrumento en la toma de decisiones: el caso de Guadalajara, Mexico. (Tesis Doctoral). Universidad de Guadalajara-Universidad de Málaga. Obtenido de Universidad de Guadalajara : https://core.ac.uk/download/pdf/62903024.pdf 
Goodrick, D. (2014). Estudio de caso comparativo. Italia: Fondo de las Naciones Unidas para la Infancia (UNICEF). Obtenido de https://www.unicef-irc.org/publications/pdf/MB9ES.pdf

GoRaymi. (21 de junio de 2018). Historia del Turismo. Ecuador. Obtenido de https://www.goraymi.com/esec/ecuador/historia/historia-turismo-ah3lh5o0h

Hernández, R., Fernández, C., \& Baptista, P. (2014). Metodología de la Investigación. México: McGraw - Hill. Obtenido de https://www.uca.ac.cr/wp-content/uploads/2017/10/Investigacion.pdf

Instituto Nacional de Administración Pública A.C. (2014). La función social de los observatorios. El caso del Observatorio Latinoamericano de la Administración Pública. Toluca: Instituto Nacional de Administración Pública, A.C. Obtenido de http://www.inap.mx/portal/images/pdf/book/praxis154.pdf

Mendoza, E., Yumisaca, J., Freire, M., \& Ullari, N. (2016). Observatorio turístico: Una herramienta de gestión para el turismo de sol y playa en la provincia de Santa Elena. Revista Científica y Tecnológica UPSE, 3(3), 172 - 185. Obtenido de https://incyt.upse.edu.ec/ciencia/revistas/index.php/rctu/article/view/210/pdf

Ministerio de Turismo. (13 de Enero de 2017). Observatorio de Turismo de Galápagos. Obtenido de turismo.gob.ec: https://www.turismo.gob.ec/el-observatorio-de-turismo-de-galapagos-cumple-6-anos-degestion-interinstitucional/

Ministerio de Turismo. (19 de septiembre de 2018). Análisis Macro Económico. Ecuador. Obtenido de https://servicios.turismo.gob.ec/index.php/turismo-cifras/2018-09-19-20-08-01/analisis-macroeconomico

Ministerio de Turismo. (15 mayo 2020). Movimientos Internacionales. Ecuador. https://servicios.turismo.gob.ec/index.php/turismo-cifras/2018-09-19-17-01-51/movimientosinternacionales

Observatorio de turismo Galápagos. (2011). Obtenido de observatoriogalapagos.gob.ec: https://www.observatoriogalapagos.gob.ec/

Observatorio de Turismo Sostenible del Caribe (2020). Observatorio de Turismo Sostenible del Caribe. Obtenido de http://obturcaribe.ucr.ac.cr/

Observatorio Turístico de Euskadi. (2014). Observatorio Turístico de Euskadi. Obtenido de observatorio turisticodeeuskadi.basquetour. net: http://observatorioturisticodeeuskadi.basquetour.net/

Observatorio Turistico de Guanajuato. (2013). ¿Qué es el observatorio turístico de Guanajuato? Obtenido de observatorioturistico.org: http://www.observatorioturistico.org/oteg

Observatorio Turístico de República Dominicana (2015). Observagtorio Turístico de República Dominicana. Obtenido de http://mitur.gob.do/presentan-primer-observatorio-turistico-de-santo-domingo/

Observatorio Universitario de Turismo Sostenible y Cambio Climático (2015) Observatorio Universitario de Turismo Sostenible y Cambio Climático. Obtenido de https://outscc.unah.edu.hn/

Sarmiento, Y., Delgado, M., \& Infante, M. (2019). Observatorios: clasificación y concepción en el contexto iberoamericano. Revista Cubana de Información en Ciencia de la Salud, 30(2), 1 - 28. Obtenido de https://www.medigraphic.com/pdfs/acimed/aci-2019/aci192g.pdf

Secretaria Nacional de Planificación y desarrollo . (2019). Agendas Zonales. Zona 4 - Pacífico. Manta : Senplades.

Soto, F. (2017). Elementos teóricos y conceptuales para la observación y monitoreo del territorio turístico bajo criterios de sostenibilidad. Pereira: Universidad Tecnológica de Pereira. Obtenido de 
http://repositorio.utp.edu.co/dspace/bitstream/handle/11059/7972/3384791S718.pdf?sequence=1\&isAll owed $=y$

Tono, G. (2011). La utilización del método comparativo en estudios cualitativos en ciencia política y ciencias sociales. KAIROS, 15(27), 1 - 12. Obtenido de http://www.revistakairos.org

Universidad de Málaga. (2008). Málaga ciudad genial. Observatorio Turístico . Obtenido de malagaturismo.com: http://www.malagaturismo.com/es/paginas/observatorio-turistico/410

Universidad de San Martín de Porres. (2018). Observatorio Turístico del Perú. Obtenido de observatorioturisticodelperu.com: http://www.observatorioturisticodelperu.com/

Universidad Espíritu Santo. (2014). Guayaquil cuenta con un observatorio turístico. Obtenido de guayaquilesmidestino.com: https://www.guayaquilesmidestino.com/es/noticias/guayaquil-cuenta-conun-observatorio-turistico

Universidad Estatal Amazónica. (2018). Observatorio turístico. Obtenido de uea.edu.ec: https://www.uea.edu.ec/?page_id=2378\#1530745090964-3ec57990-2867

Universidad Estatal Península de Santa Elena. (2017). Observatorio Turistico sostenible . Obtenido de observatorioturistico.upse.edu.ec: http://observatorioturistico.upse.edu.ec/

Universidad Técnica Particular de Loja. (2016). Observatorio Turístico Región Sur del Ecuador. Obtenido de observatorioturistico.utpl.edu.ec: https://observatorioturistico.utpl.edu.ec/

Universidad Tecnológica de Pereira. (2009). Observatorio Turístico Sostenible Eje Cafetalero. Obtenido de observatorioturismosostenible.blogspot.com: http://observatorioturismosostenible.blogspot.com/

Esta obra está bajo una Licencia Creative Commons

Attribución-NoCommercial 4.0 International

(cc) BY-NC 